\title{
Proposition of Thetical and Antithetical Economic Line
}

\author{
Eizo Kinoshita, (PhD) \\ Meijo University, Japan
}

doi: 10.19044/esj.2016.v12n31p1 URL:http://dx.doi.org/10.19044/esj.2016.v12n31p1

\begin{abstract}
In this paper, the author proposes a developed version of "Thetical and Antithetical Economics" (12)(14), a theory proposed earlier by himself. In doing so, he first defines the nature of "inflationary gap" and "deflationary gap," respectively, followed by an in-depth analysis of "Thetical and Antithetical Economic Line," by examining real-life examples in Japan, the United States and Germany during the first half of the 20th century. In the subsequent discussion of "Thetical and Antithetical Economic Line," he clarifies how an "antithetical bubble" has been created. In the end, he goes on to give a thorough description of the true identity of "deflationary gap."
\end{abstract}

Keywords: Macroeconomics, Thetical and Antithetical economics, Bubble economy

\section{What is a "deflationary gap"?}

Is the Japanese economy truly in a state of slump? The author believes that the answer is "no," because the present situation is quite different from any conventional forms of economic depression people have been familiar with. Japanese Prime Minister Shinzo Abe and Bank of Japan (BOJ) Governor Haruhiko Kuroda simply misinterpret the current situation as "an economic slump." This is because booms and busts of an economy can only take place during a "thetical economy," but Japan is currently in an "antithetical economy," where there can be no economic booms and busts, and where an economy simply stagnates.

Both the Japanese government and BOJ, failing to perceive the fact that Japan is in an "antithetical economy," erroneously decided that the Japanese economy is in a slump. Thus, all their attempts, including "Abenomics" and "unprecedented scale of monetary easing," have not produced any intended effects, because they are based on the flawed logic. 
Then, why do their attempts fail to work? The cause is clear if we understand the properties of a "thetical economy" and an "antithetical economy."

What divides a "thetical economy" and an "antithetical economy" is whether there is "deflationary gap" or not. Deflationary gap emerges when the productive potential of an economy exceeds aggregate demand. Let's look at the following example to help understand this.

Suppose that there are a monkey, a dog and a pheasant, and that each of them wants to drink a cup of coffee. Then, suppose that a coffee vendor who only has two cups worth of coffee in stock comes along. In this case, the aggregate demand is three cups of coffee, but the vendor can only supply two cups of coffee. As a result, demand exceeds supply. And this state is "inflationary gap (supply > demand)."

Under this circumstance, it would be natural for the coffee vendor to try hard to make more coffee, to boost his or her sales. The vendor's effort to enhance his or her sales is a virtue, as was indicated by Max Weber. And if the coffee vendor produces another cup of coffee, supply and demand are balanced and reach equilibrium. This state is called a "thetical economy." In other words, in a "thetical economy," there is no deflationary gap; instead it is prone to create an inflationary gap. That is to say, in a "thetical economy," the coffee vendor tends to work hard to reach equilibrium, trying to adapt him or herself to this inflationary gap-prone state. It is obvious that French economist Jean-Baptiste Say's law, or "aggregate production necessarily creates an equal quantity of aggregate demand," is valid in this state.

However, what if the monkey, dog and pheasant each starts drinking five to even ten cups of coffee a day? The coffee vendor, who could easily produce another cup of coffee, might be unable to meet a sudden rise in the number of orders, or demand, and might end up raising the price of coffee.

Such a state is called a bubble. Tulip mania in the Netherlands during the 17th century is considered the first recorded speculative bubble. Many consumers tried to get bulbs of this exotic plant, which boosted the prices of bulbs to extremely high levels. The price of a single bulb was said to equal 25 years' income of a general worker at that time.

The author calls this a "thetical bubble," or a bubble in "thetical economy," which is to be created as a result of insufficient supply. In other words, this is a state where aggregate demand sharply exceeds supply.

The author then examines a different circumstance: What would happen if a coffee vendor with 20 cups of coffee in stock comes along, when the aggregate demand for coffee remains the same, or three cups, one each for a monkey, a dog and a pheasant. In this case, supply exceeds well beyond the aggregate demand for coffee. And this state is called "deflationary gap." That is to say, it is a state where supply is well above demand. 
Because their demand for coffee has been met, it is not possible for the vendor to sell more cups of coffee. Thus, when demand is fully satisfied, a coffee vendor becomes unwilling to produce more coffee, although he or she has the capacity to do so. The vendor in such a circumstance might naturally be unwilling to make fresh capital investments, such as purchasing a mill to grind more coffee beans. By the same token, a coffee farm, providing the vendor with coffee, would be unwilling to extend its farm areas to produce and supply more coffee beans when there is little chance for more sales.

All that the coffee vendor and the coffee farm could do is to decrease the amount of coffee supply to a level just enough to satisfy the demand of the three coffee drinkers. And under this circumstance, suppliers would not dare to increase their coffee production. Instead, they would refrain from making fresh capital investments, even if they have surplus cash. This is a state where a law that "aggregate demand creates an equal quantity of aggregate production" is valid, which is the opposite of Say's law that "aggregate production creates an equal quantity of aggregate demand."

Coffee was used as an example to help simplify the analysis, but if coffee is replaced by goods and services, and if the three animals are replaced by consumers, it is clear that the example of coffee in fact denotes the current economic circumstance in Japan.

And the above-mentioned example of coffee is exactly what Japan faces today: Because the aggregate demand is only three cups of coffee, despite its capacity to serve 20 cups of coffee, manufacturers are unwilling to produce more coffee, and refrain from making fresh capital investment.

\section{What is "Thetical and Antithetical Economic Line"?}

The above-mentioned economic change can be depicted by a single line, called "Thetical and Antithetical Economic Line" (proposed by Eizo Kinoshita) in this paper, as is shown in Chart 4. But before explaining "Thetical and Antithetical Economic Line" in Chart 4, let's look at Chart 1, a basic graph utilized in economics textbook by Paul Samuelson. 


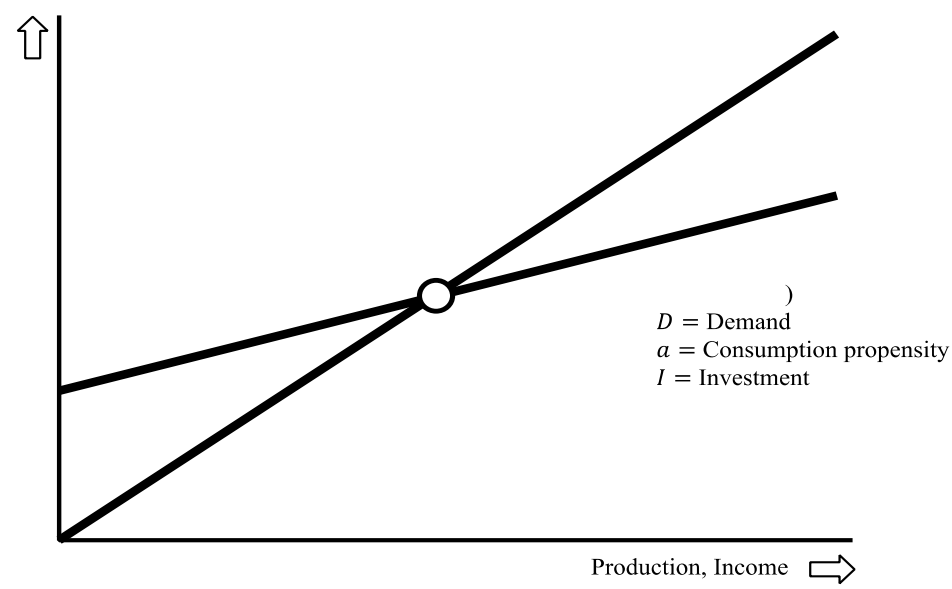

Chart 1. Basic graph in economics textbook by Paul Samuelson.

The intersection of supply function and demand function denotes equilibrium. That is to say, a state where three cups of coffee were requested and supplied. As this chart shows, the gap between supply and demand conforms at equilibrium, and there are no deflationary and inflationary gaps.

But the equilibrium point changes greatly when a bubble emerges. In a bubble, firms start making more investments and consumers tend to spend more, which ends up pushing the equilibrium to upper right. The gap between the original point of the equilibrium before the emergence of a bubble, and the one reached with the bubble denotes "inflationary gap," as is shown in Chart 2.

Chart 2 demonstrates that "marginal propensity to consume," which is denoted by demand function "a," gets higher when a bubble emerges, bringing the line to move upward at a steeper angle.

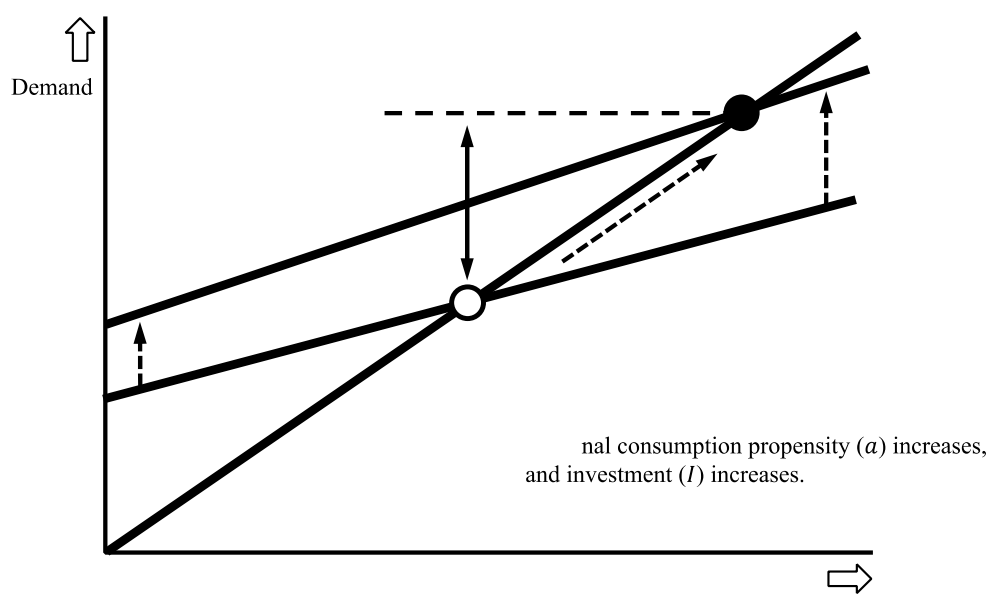

Chart 2. Inflationary gap in bubble economy. 
The notion of this "marginal propensity to consume" can be easily understood through an annual income example. Suppose a person's annual income increases by 1 million yen. Then, how much of it would he or she consume? And "marginal propensity to consume" signifies the ratio of consumption.

For example, if he or she prefers to spend 800,000 yen out of 1 million yen in his or her annual income increase, and save the rest, or 200,000 yen, "marginal propensity to consume" turns out to be 0.8 . The money he or she spent, or 800,000 yen in this case, would flow into firms, and the deposited money of 200,000 yen would be financed to firms through his or her bank. Firms, by getting loans, might increase capital investment, or use the loans to pay salaries to their employees. As long as such a circulatory flow of money continues in this manner, there would never be deflationary gap.

With the emergence of a bubble, "marginal propensity to consume" gets higher. This is because people start to think "we should spend more, and buy more tulip bulbs, more stocks now because their prices might go up." The value of "marginal propensity to consume" could exceed 1, as speculative craze gets more and more overheated and people become more willing to engage in speculative investments even by taking loans.

However, a bubble inevitably bursts. Then, firms refrain from making investments, and consumers stop spending, which brings the value of "marginal propensity to consume" to go down. Housing prices might plunge, for example, from 30 million yen to 10 million yen, or almost one-third of their original prices.

And the owners of those houses, who are debt-ridden, might end up selling their houses, which is still not enough to pay all their debts. Suppose such an owner still has 10 million yen in debts, for example. That person should certainly refrain from spending and try to pay back the debts, even when his or her salary gets slightly higher.

Such aftereffects of the burst of a bubble generally bring the slope of demand function to a milder angle, leading equilibrium to move largely down to the left. The gap between the original equilibrium and the one reached after the burst of a bubble denotes "deflationary gap” (Chart 3). 


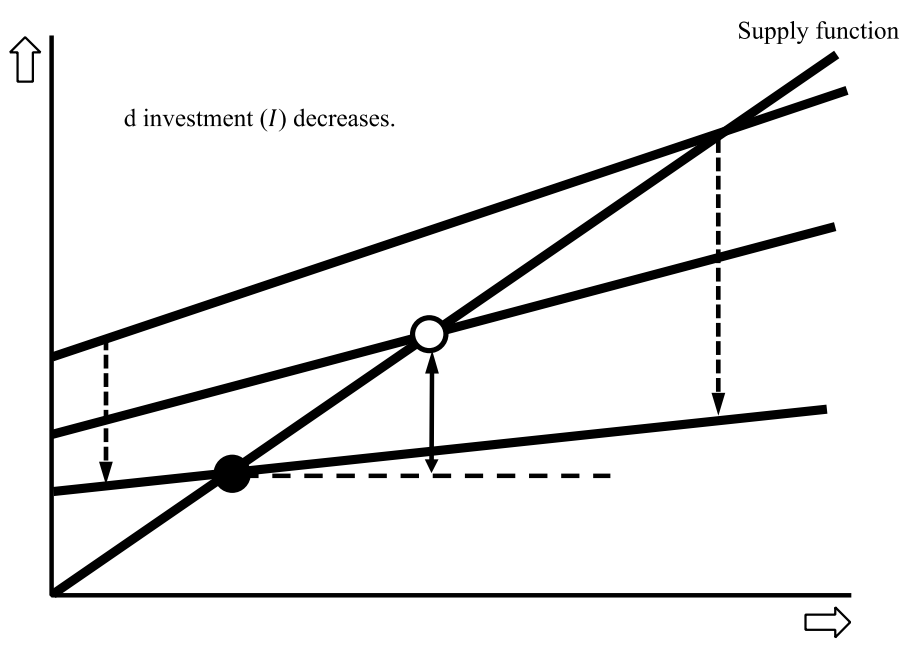

Chart 3. Deflationary gap after burst of bubble.

By the same token, it is possible to identify inflationary gap as well as deflationary gap in Chart 1, or Samuelson's chart. But doing so is slightly complicated.

Thus, the author picks out inflationary gap and deflationary gap, or gaps between demand and supply, from Samuelson's chart, and demonstrates the result in Chart 4 . The line shown in Chart 4 is what the author calls “Thetical and Antithetical Economic Line." In Chart 4, it is obvious that a single line depicts the transition of the Japanese economy during the first half of the 20th century, which covers from the emergence of a bubble and its burst during the Taisho period (1912-1926), through to Japan's economic recovery after World War II.

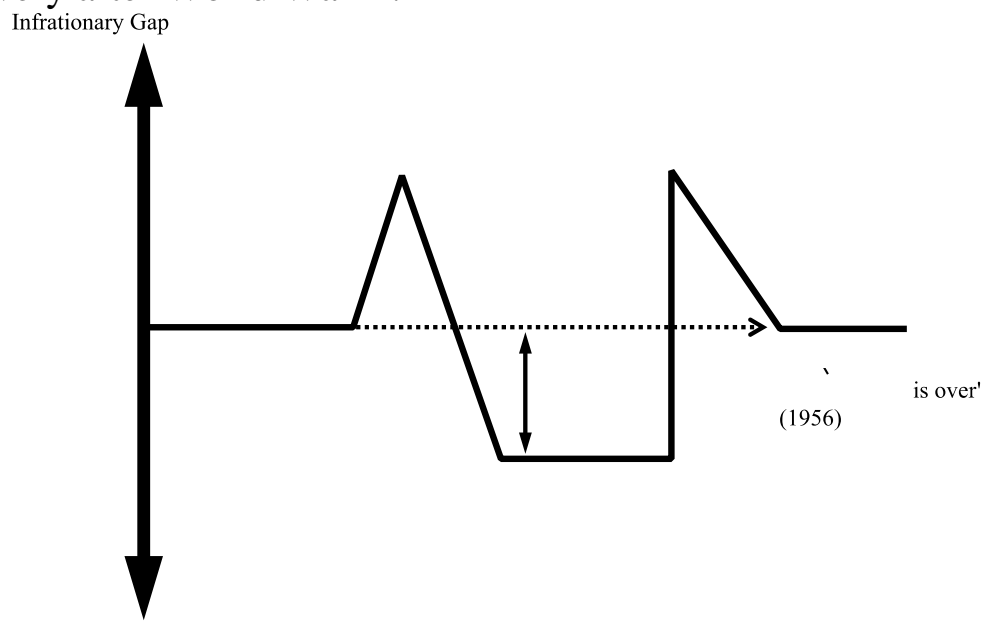

Chart 4. "Thetical and Antithetical Economic Line" in Japan during the first half of 20th century. 
In this "Thetical and Antithetical Economic Line" chart, the vertical axis denotes a gap between supply and demand, and the horizontal axis represents the flow of time. The center at the vertical axis is equilibrium. It is visible from Chart 4 that there emerges an inflationary gap when "Economic Line” comes above the equilibrium, and that there is a deflationary gap when the line is below the equilibrium.

In other words, in this chart, the economy is in a thetical economic phase if "Economic Line" is above the equilibrium, while it is in an antithetical economic phase when the line is below the equilibrium. Here, it is significant to note that "Economic Line" only demonstrates whether there is inflationary and deflationary gap or not, and that ups and downs of the line do not reflect the booms and busts of an economy. "Economic Line" always exists, regardless or time and place. That is to say, it exists in the United States, or in Japan, Sudan or Papua New Guinea. It also existed whether it was during the Edo era (1603-1868) or the Muromachi era (1336-1573), as it exists today, because the line simply denotes a gap between demand and supply.

\section{"Thetical and Antithetical Economic Line" in Japan during the first half of the 20th century}

The Japanese economy was in "thetical phase" at the beginning of the 20th century. Even though the economy followed a normal boom-bust cycle, and was not free from inflationary gap, supply and demand was basically kept in balance during this period. In other words, it was a state where the theory by Adam Smith was applicable.

World War I broke out in 1914. Because the battles were fought away from Japan, and mostly in Europe, the Japanese economy boomed, supported by the development of export industries, namely heavy industries. The war boom, which coincided with Taisho era in Japan, created an economic bubble called the "Taisho Bubble." As is shown in Chart 4, "Economic Line" which remains flat in a "thetical economy," makes a steep rise towards the peak of the bubble. The steep rise of "Economic Line" signifies the emergence of an inflationary gap.

But the bubble did not last long. The Japanese economy depressed with the end of the war and the collapse of the bubble. The depressive state got even worse in the aftermath of the Great Depression, which was triggered by the U.S. stock market crash. Because the depressive period coincided with the Showa era (1926-1989) in Japan, it is called the "Showa Depression.”

Demand plunged with the burst of the Taisho Bubble, which gave rise to a deflationary gap. Chart 4 shows that "Economic Line" goes down, which denotes that the Japanese economy went into an "antithetical 
economy.” During this period, Korekiyo Takahashi, then Minister of Finance, came out with extensive pump-priming measures, and issued deficit bonds to boost war industries, even before the U.S. Government enacted New Deal policies. Takahashi, while working out the government policies to create demand, spent extravagantly as a consumer, saying "spending is a virtue." In other words, he tried to help the Japanese economy get out of an antithetical economic phase, by taking the lead in the efforts to spend more, although he must have been unaware of the "Paradox of Savings."

However, he soon detected a sign of inflation, and tried to cut back on military spending. But his action provoked violent opposition by young Japanese military officers, who assassinated Takahashi in February 1936. With the assassination of Takahashi, the deflationary gap was kept unsolved, which eventually led Japan to go into another war.

Most parts of Japan, except for Kyoto, Nara and Hokkaido, were bombed during World War II, and almost all of its sources of supply were destroyed. The nation's supply, which always surpassed demand, plunged to a near zero level after the war. That is to say, "supply > demand" state changed into "supply < demand" state.

This state is visible at the point where "Economic Line" shot up vertically in Chart 4. It is obvious that an inflationary gap swiftly came into being, even skipping the process of deflationary gap dissolution. In other words, because its supply sources were diminished to a near zero level through the air strikes during the war, the deflationary gap, which had been in the Japanese economy since before the war, was quickly dissolved, which helped Japan to get out of an "antithetical economy."

But Japan was hit by inflation almost at the same time, because there was virtually no means of production despite demand. Thus, Japanese people were obliged to build temporary shelters on the devastated lands, then they went on to construct roads and factories, and in this manner, they eventually reconstructed the economy. By 1955, Japan recovered its supply capacity well enough to be able to dissolve the inflationary gap, supported by the Korean war boom. The government's 1956 annual economic report also announced, "the post-war period was over," which became one of the most fashionable phrases used among people at that time. Indeed, the inflationary gap was dissolved and Japan shifted into a "thetical economy." Shortly after, the rapid economic growth period began.

\section{"Thetical and Antithetical Economic Line" in the United States during the first half of the 20 th century}

Now the author examines "Economic Line" of the United States during the first half of the 20th century (Chart 5). 


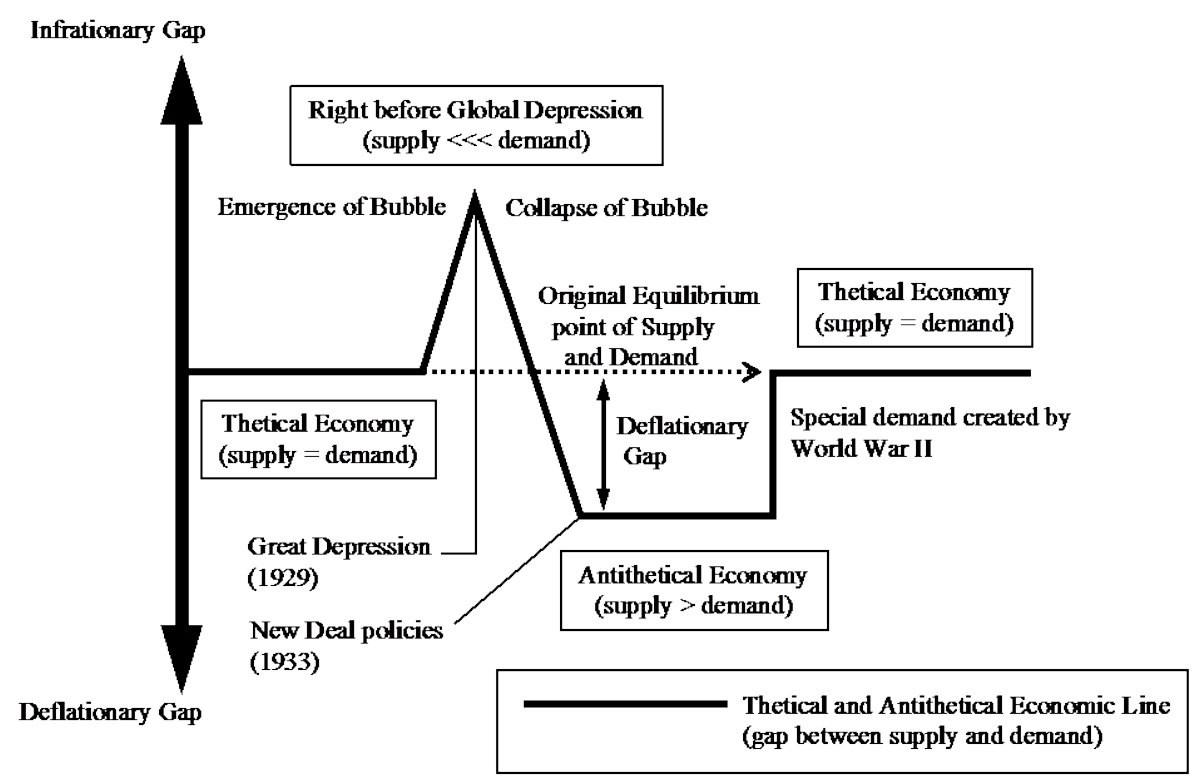

Chart 5. "Thetical and Antithetical Economic Line" in the United States during the first half of 20th century.

Because all the battles were fought away from the United States during World War I, it won victory without suffering any war damages. Thus, with the end of the war in 1918, the country became a major exporter of materials, and its economy boomed. Much capital flew into the country, and soon it started prospering as a global economic center, replacing the wardevastated Europe. As U.S. living standards went up, the demand for industrial products such as radios and cars also increased, which further boosted the economy.

During the 1920s, the Dow Jones average jumped from 65 dollars to 380 dollars, and a bubble emerged, denoted by the point at which "Economic Line" shot up steeply in Chart 5 . However, all bubbles inevitably burst. In October 1929, stock prices crashed in New York, which is known today as Black Thursday.

Compared with the level immediately before the crash, New York stock prices plunged by over 80 percent, whose after effects diminished more than two-thirds of the national industrial production. Nearly 12 million people lost their jobs, with its unemployment rate exceeding 25 percent.

The great depression prompted by the Black Thursday market crash engulfed not only the United States, but also Europe and Japan, thrusting those industrialized countries into a panic. U.S. President Herbert Hoover, a Republican, decided to keep Treasury Secretary Andrew Mellon, a banker, and attempted to stabilize the economy by pursuing his pet theory, or restoring finance and reducing tax. 
In 1930, he enacted the Smoot-Hawley Tariff Act, which was criticized as the "worst tariff bill in U.S. history." With the legislation, tariffs on imported goods were raised to over 50 percent in the next four years. But its trade partners like Britain, France, the Netherlands, Belgium and Spain also raised their tariffs on imports from the United States in retaliation.

As a result, U.S. exports declined sharply, which worsened the depression, bringing the global economy into a critical condition. In short, the U.S. economy, which was in a thetical phase, eventually brought about a bubble, and its bursting led it into a state of depression, which induced the global depression. Thus, the economy moved into an antithetical phase.

In 1933, Hoover left Washington and Franklin Roosevelt, a Democrat, became President. He started extensive public projects called the "New Deal," which accompanied a drastic increase in public spending on social capital, such as the construction of dams and roads.

Theories proposed by John Maynard Keynes were much embraced during this period, because the "Paradox of Savings," a theory he established, was valid because the economy was in an antithetical phase: Consumers refrained from spending, and tried to save more; Firms preferred to repay debts, instead of maximizing profits, and refrained from making fresh capital investment.

Thus, in pursuing the New Deal policies, the U.S. government took the initiative, instead of submitting to "an invisible hand," and intervened in the market, while trying to make up for a shortfall in demand in firms and consumers, just as Keynes advocated.

The U.S. government's extensive fiscal actions helped ease the depression by 1936. However, in 1937, the government made a policy shift and placed higher priority on financial reconstruction, by reducing its expenditure on a dramatic scale. However, because the U.S. economy was yet to return to a "thetical economy," it fell again into a depressive state, called the "Roosevelt Depression."

As the U.S. example shows, financial reconstruction in the middle of an "antithetical economy" could deteriorate an economy even worse, hindering greatly the process of getting out of an "antithetical economic phase.”

\section{How the United States got out of an "antithetical economy"?}

Then, how did the United States dissolve the deflationary gap and get out of its “antithetical economy”? Many insist that "New Deal policies were successful in getting out of it.”

That is not true. The United States got out of its "antithetical economy" because of World War II. Although it does not mean that Keynes' theory was wrong, but a true cause which helped the United States get out of 
its "antithetical economy” during the first half of the 20th century was the war, and not the Keynesian policy of the New Deal.

With the start of the war with Japan, the United States increased the government expenditure by issuing war bonds on a dramatic scale. The U.S. unemployment rate fell to 1.2 percent in 1944, and the booming war industries helped dissolve the deflationary gap.

There is also another important factor which enabled the United States to resolve the deflationary gap. It is obvious if we think where the battles were fought during the war. They were mostly fought in Europe, on islands in the Pacific, as well as in China, but not on the American continent. Hawaii, which suffered a surprise attack by Japan, was the only exception.

This means that the supply capacity of the United States was kept intact during the war, in total contrast to Japan. Many parts of the Japanese mainland were attacked, and the country lost most of the sources for supply. In Japan, the war helped eliminate the deflationary gap, but the destruction of its supply sources brought about an inflationary gap at the same time. On the other hand, the United States, away from the battlefields during the war, with its supply sources preserved intact, enjoyed the war boom which was instrumental in creating more demand than supply, which quickly helped its economy proceed into a thetical phase.

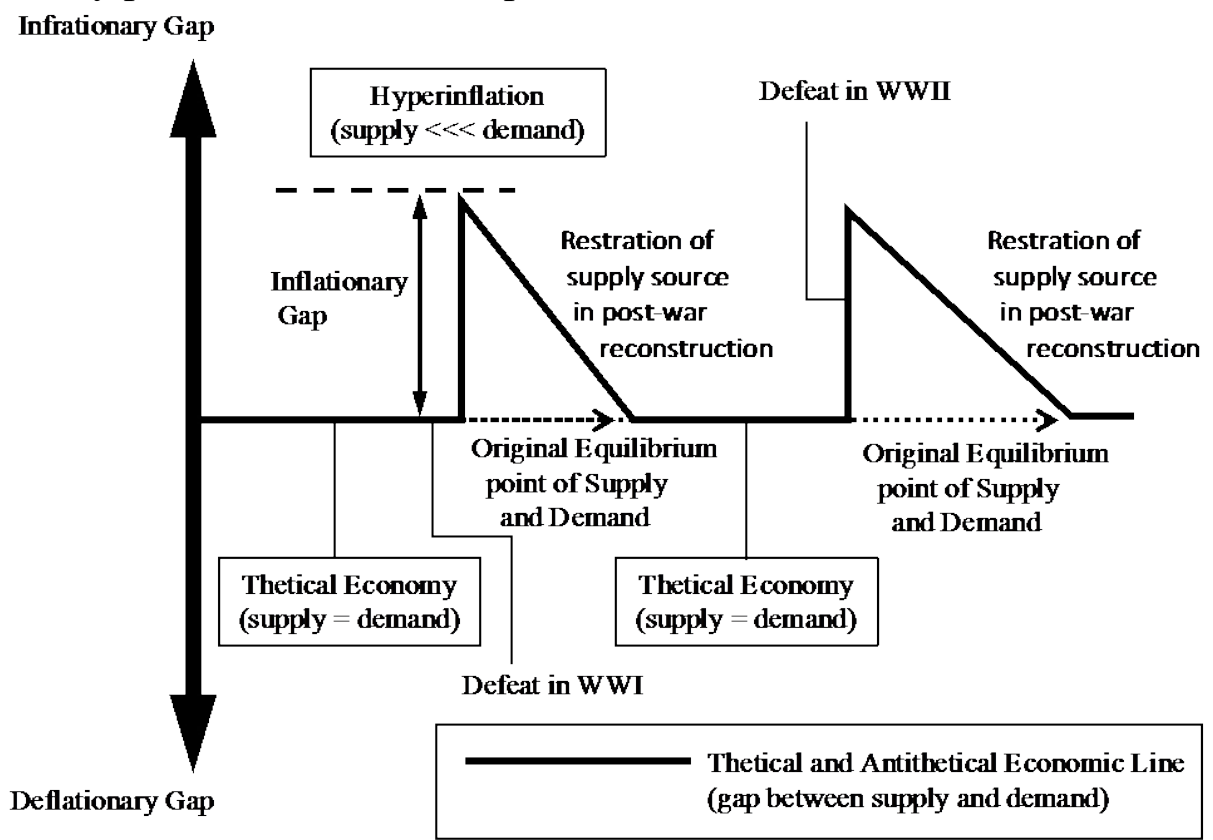

Chart 6. "Thetical and Antithetical Economic Line” in Germany during the first half of 20th century 


\section{German defeat in the war eliminated inflationary gap}

Next, the author examines "Thetical and Antithetical Economic Line" of Germany, another participant of the two wars, as shown in Chart 6. Unlike Japan and the United States, whose economies boomed through World War I, Germany (then Weimar Republic) suffered the war devastation, and was defeated in the war. Hyperinflation hit the nation right after World War I. It is true that Japan was also hit by hyperinflation after World War II, but the inflation Germany experienced right after World War I was even worse. In fact, it was so violent that the price of a loaf of bread rose to 1 trillion marks.

Germany was then hit by the subsequent Great Depression, originated in the United States, which engulfed the entire European continent. Amid the growing social unrest, Nazi Germany came into power, by promising work and bread for all the people.

Adolf Hitler did exactly what Japan's Finance Minister Korekiyo Takahashi had done, but Hitler did it on a larger scale. For instance, the Nazi government constructed autobahns, a highway network across the nation, a public project of an unprecedented scale.

But it should be noted that Germany at that time was not in an "antithetical economy.” The German hyperinflation right after World War I was in essence an "inflationary gap." And there had never been a deflationary gap in Germany, unlike the United States and Japan, as is shown in Chart 6.

There was no bubble in Germany before the Great Depression, and the economy was in a thetical phase. Thus, during the Great Depression, although its economy suffered a slump which is commonly observed during a thetical economic phase, it was free from deflationary gap.

In other words, the extensive public projects like the construction of the autobahns, helped the country return to the growth track of a "thetical economy" after World War I. Although some insist that "economic policies by Hitler created the boom," but as "Economic Line" in Chart 6 demonstrates, all Hitler did was to restore the war-damaged supply sources through public projects, as part of the country's post-war reconstruction efforts.

Germany again became a battleground during World War II, which destroyed its supply sources. But unlike Japan, it took much more time for Germany to restore the economy. This was because the division of the country impeded the restoration of its supply sources, and also because no war-related demand, like the Korean war for Japan, was created. Thus, it took a longer time, than Japan, for the country to eliminate the inflationary gap. 


\section{Why unprecedented an "antithetical bubble” emerged?}

Since the author believes that the analysis of the examples of Japan, the United States and Germany, helped clarify the essence of "Thetical and Antithetical Economic Line,” it is important to return to the examination of the Japanese economy once again, by using this line.

After World War II, Japan's policy objective completely changed, and making itself an economic power, instead of a military power, became its primary national goal. The Cold War confrontation of the western and the eastern bloc nations, led by the United States and the Soviet Union, respectively, worked favorably for the Japanese economy.

There were also some "windfall" incidents, which profited its economy: Japan was not divided, despite its defeat in the war, and this was fortunate for its economy. This was because the division might have caused serious damage to its economic development, which was obvious from the German and Korean cases.

Japan was placed under the administration of the United States, and made a fresh start to become "a global factory," under the guidance of General Headquarters. Japan could allocate much of its resources to increase productivity, because Article 9 of the constitution stipulates that Japan should limit its military cost to around one percent of its gross domestic products (world average is around two percent).

The outbreak of the Korean and Vietnam wars, created through the rivalry between the United States and the Soviet Union, pushed the Japanese economy to grow further, because they boosted war-related demand. Although Japan suffered slight damage from the two oil crisis during the 1970s, it continued to grow to be the second largest economy in the world.

But as the economy continued a rapid growth, a wrong belief that "stock and land prices would go up forever" was reinforced among Japanese people, which inspired more and more people to invest in real estate in the central parts of Tokyo. At the peak of the bubble, it was claimed that "the total land price of the 23 wards in Tokyo is equivalent to that of the whole land space of the United States.” The Nikkei Stock Average hit a historic high of 38,915 yen on December 29, 1989, the final session of the year.

However, a bubble inevitably bursts. And shortly, Japanese stock prices started to plunge, along with land prices, which left a serious aftermath in the form of huge amount of bad loans.

The course of the above-mentioned events is depicted by "Thetical and Antithetical Economic Line” in Chart 7. 


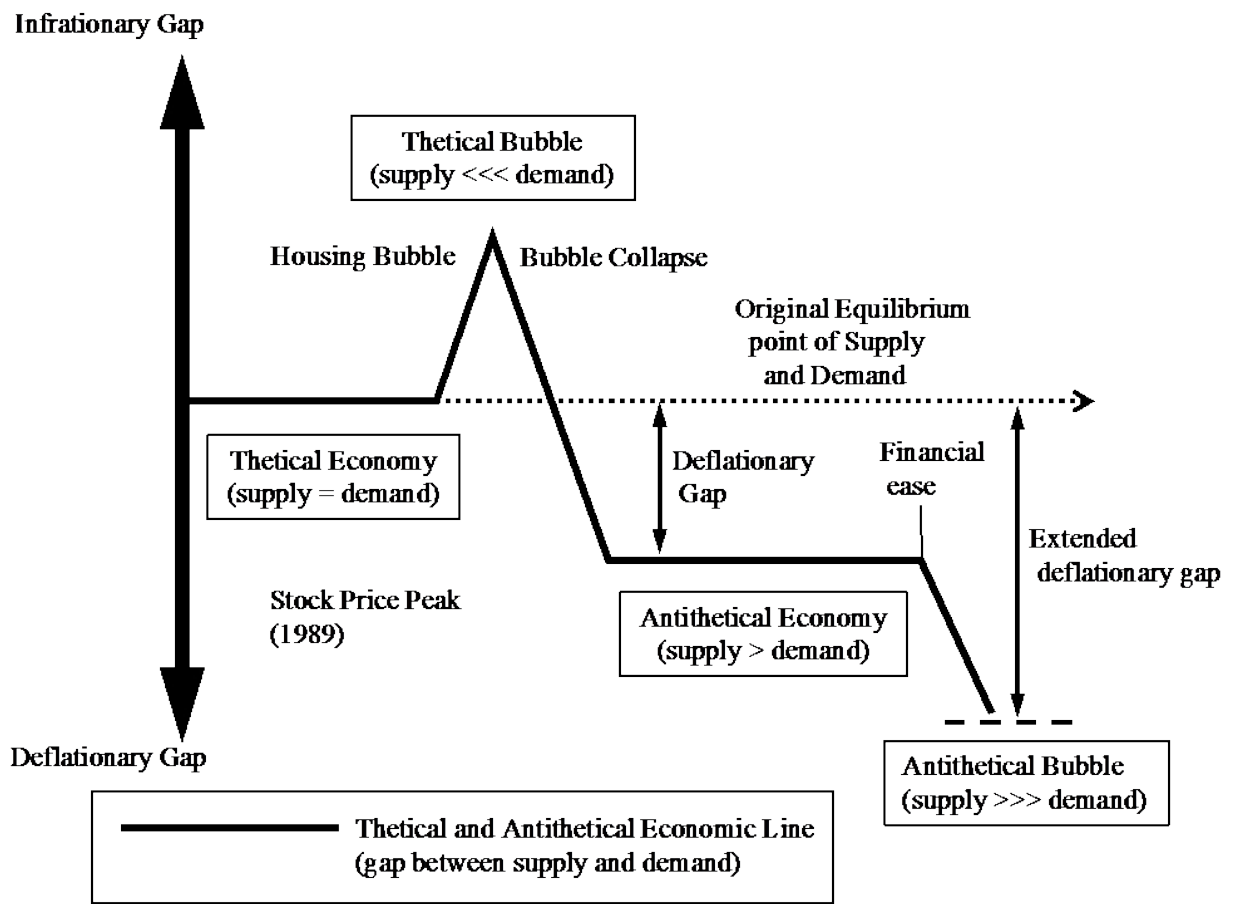

Chart 7. “Antithetical Bubble” today’s Japan fell in.

After the burst of the bubble, the Japanese economy fell into an antithetical phase. The subsequent long depression was called the "lost decade." But another decade passed after that, which was then called the "two lost decades," and the depressive state continues up to the present.

What is more, the deflationary gap in the Japanese economy is growing today due to the repeated easing measures by BOJ, which is fueling a money glut to reach a level as to create "an antithetical bubble," the first of its kind in human history.

If easing measures on "an unprecedented scale" are to be carried out when there is a deflationary gap, surplus money should naturally flow into stock markets.

That is to say, a rise in stock prices, as a result of such easing measures by a central bank, is a "fake," or a result of artificial creation. This is because the money that flows into stock markets is essentially the same as the "money tucked away in banks," which is a true identity of the deflationary gap today. 


\section{Behavioral principle of firms and consumers in an "antithetical economy”}

Firms in a "thetical economy" seek to obtain bank loans for capital investment in order to increase profits, while consumers in this economic phase tend to spend more on goods and services, while they continue to save.

Banks furnish firms with funds they obtained from consumers in the form of deposits, then firms invest the money they get from banks in the form of loans, on capital assets to gain profits, which are to be paid to consumers in the form of salaries. Consumers then save part of their salaries, and purchase new goods and services. Money in this phase continuously flows through firms, consumers and banks, as shown in Chart 8.

Consumption

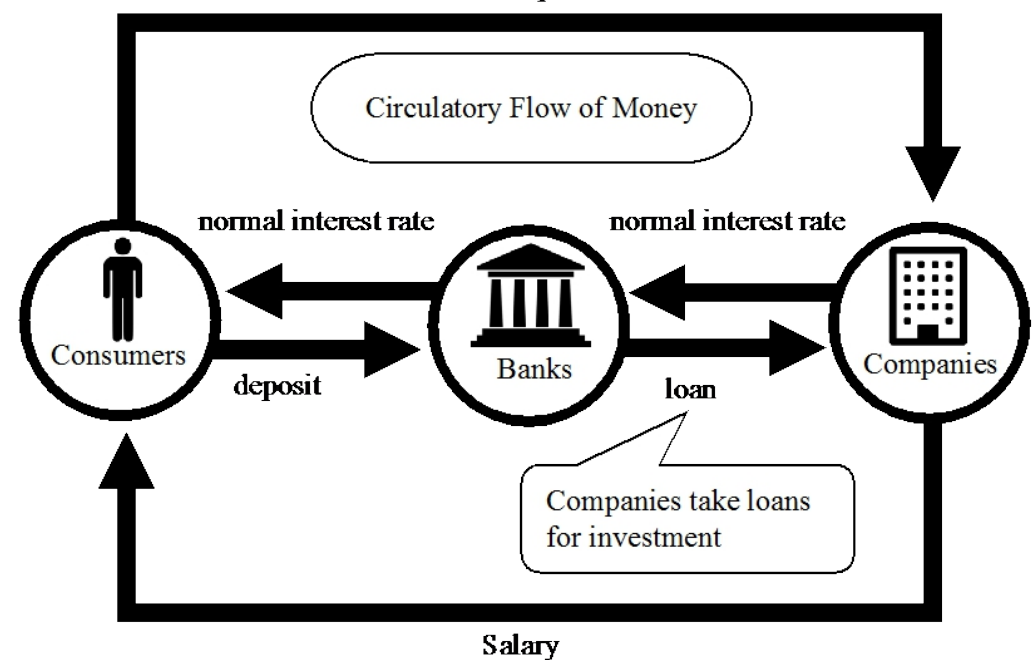

Chart 8. Circulatory flow of meney in "Thetical Economy."

In an "antithetical economy," however, money stops flowing and is tucked away.

Economic statistics during the first half of 2016 show that Japanese companies refrain from making fresh investments, although some firms have enjoyed the highest-ever profits, benefited by the deflated value of yen. Then, why are they unwilling to make capital investments at home? The answer is quite simple: This is because "making domestic capital investments is unlikely to bring any profits" in Japan. Any company manager should consider investment efficiency, and decide not to do so if there is little prospect for profits.

That is to say, if a company is convinced that it can "gain 1.2 million yen by investing 1 million yen," for instance, the value of investment efficiency for the firm is larger than 1 . Under such a circumstance, then, its 
manager would be very willing to make an investment even by getting into debt.

Thus in a "thetical economy," because the value of investment efficiency surpasses 1, firms prefer to take bank loans to make fresh investments.

But when only 800,000 yen can be collected in return for 1 million yen in an investment, which means that the value of investment efficiency is less than 1, company managers should be discouraged to make any fresh investment. And this is exactly the case with Japan at the moment. Thus, company managers are unwilling to make fresh investments now, which is reflected in the slow growth of machinery orders in Japan.

Company managers are unwilling to make investments as long as the value of investment efficiency is less than 1, regardless of how hard Prime Minister Abe tries to encourage them to do so.

\section{True identity of a "deflationary gap"}

Then, a question naturally arises: What do firms do in an "antithetical economy"?

In the study of physics, it is said that "antimatter owns opposite properties of normal matter." The principle is applicable also to a "thetical" and an "antithetical economy."

"Thetical Economy" is a phase where the economics theory by Adam Smith is valid.

Adam Smith economics insists that firms as well as consumers pursue only their personal gains. Firms seek the maximization of profits, while consumers seek the maximization of efficiency. Thus, the maximization of profits and efficiency constitutes a principle which governs their behaviors in a "thetical economy."

Whereas in an "antithetical economy," they behave in an opposite way. Companies tend to seek "the minimization of debts," and consumers would seek "the minimization of expenditure."

Then the circulatory flow of money, flowing continuously through firms, consumers and banks, as shown in Chart 8, should also stop in an "antithetical economy," where consumers seek to minimize expenditure and firms seek to minimize debts, as shown in Chart 9. 


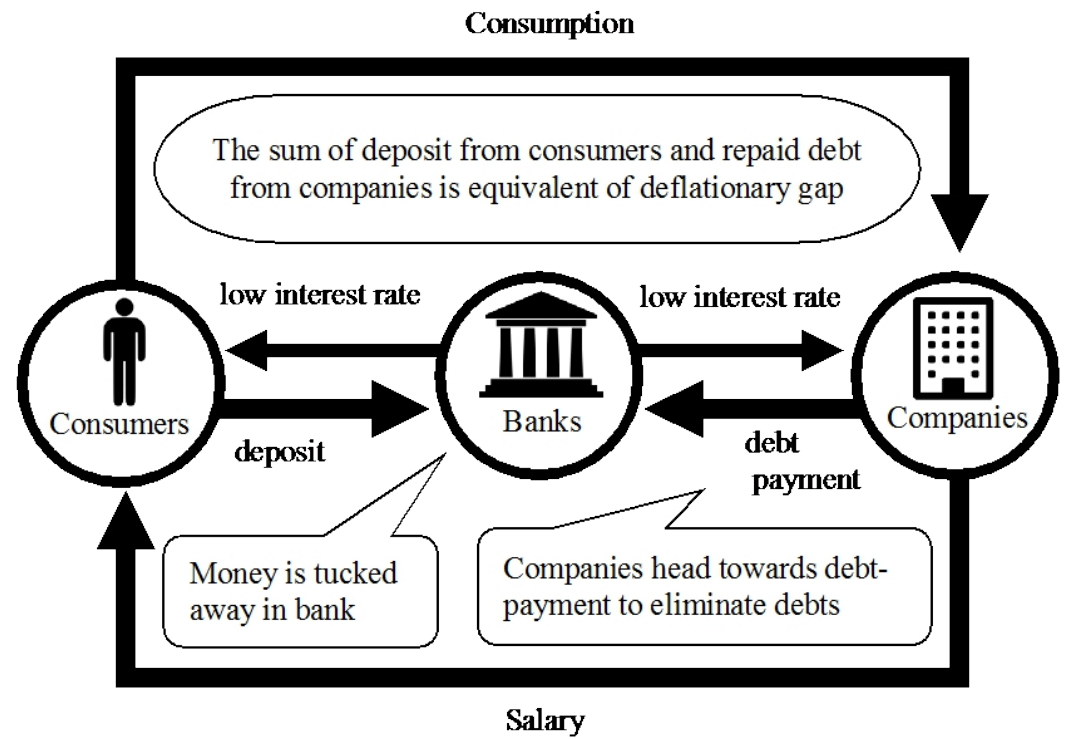

Chart 9. Why deflationary gap emerges?

Companies prefer to repay debts, even when they gain profits, because the value of investment efficiency is less than 1 , thinking that it is more efficient to pay back debts and reduce interest payment, rather than making fresh investments which is clearly unprofitable.

Consumers prefer to save more money out of their salaries, instead of buying more goods.

As a result, the amount of money in the form of paid-back debts from firms, as well as the deposits by consumers, gets tucked away in banks.

The original function of banks is to gain profits by furnishing firms with funds, after the banks get them in the form of deposits from consumers. But since firms stop borrowing money from banks, a large amount of funds ends up being stored in banks. And the money tucked away in banks is the true identity of a deflationary gap.

Japan's Cabinet Office defines a deflationary gap as "the gap between aggregate supply and effective demand," which is wrong. The true identity of a deflationary gap is the uncirculated money being tucked away in banks.

Finally, Chart 10 shows how companies tend to shun "capital investment (borrowing)" and head towards "debt repayment (saving)," when an economy moves from a thetical phase into an antithetical phase. It is obvious from the chart that non-financial firms stopped taking in loans and started paying more debts after 1995. In other words, the more companies tend to pay back debts and refrain from getting loans for fresh capital investments, the more money is being tucked away in banks. The chart also shows that companies are becoming more and more willing to accumulate 
net financial assets after 1998, as is denoted by an upward sloping curve in the chart, and such corporate behavior remains unchanged even today in Japan where Abenomics policies are being implemented.

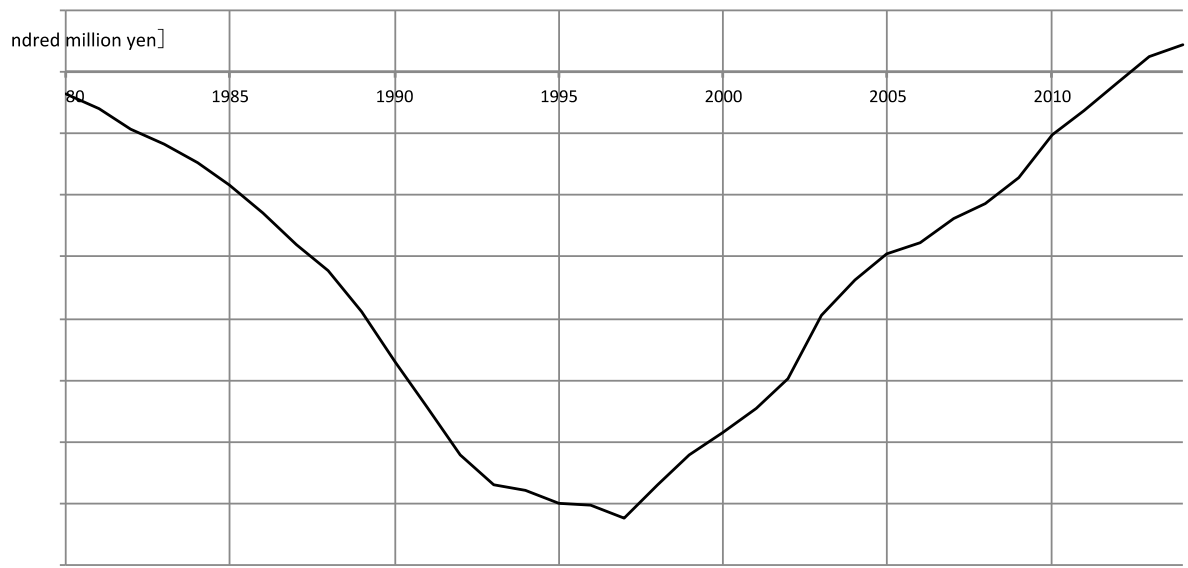

Chart 10. Financial net worth of non-financial enterprises (total) in Japan from 1980 to 2015. The data from the Bank of Japn.

\section{References:}

1. Samuelson, P. (1977) Economics (Japanese edition translated by Shigeto Tsuru). Tokyo: Iwanami Shoten

2. Kinoshita, E. (2004) Keizai wo Shihai suru 2tsu no Hosoku--Kami no Miezaru Te to Gosei no Gobiyu no Sekai (two principles control the economy---invisible hands of God and fallacy of composition). Tokyo: Denki Shoin

3. Kinoshita, E. (2009) Keizai-gaku ha naze machigae tsudukerunoka--Marukusu mo Keinzu mo minogashita 2tsu no hosoku (why economics keep on making mistakes--two principles overlooked by Marx and Kaynes). Tokyo: Tokuma Shoten

4. Kinoshita, E. (2012) Sekai ga ima ochiitteiru keizaigaku-no wana (trap of economics the world has fallen in). Tokyo: Tokuma Shoten

5. Kinoshita, E. (2012) Amerika no tsugino hakennkoku ha dokoka?: Konmeisuru sekai keizai no saki-o yomu! (which country would be a hegemon after the United States? : clarifying the future of flagging global economy!). Tokyo: Saiz_sha (ISBN 978-4883928323)

6. Kinoshita, E. (2013) Sekai Keizai no haken wo nigirunoha nihon de$a-r u$ (Japan to be the next hegemon of the world)). Tokyo: Fusosha

7. Kinoshita, E. (2013) Shinobiyoru sekai kyoko (depression is creeping up on the world). Tokyo: Fusosha

8. Kinoshita, E. and Mizuno, T. (2016) Tokei-gaku de wakaru biggu deta (big data obtained through statistics). Tokyo: JUSE Press, Ltd. 
9. Kinoshita, E. (2011) 'A Proposal of Primal and Dual Problems in Macro Economics,' Journal of China-USA Business Review, Vol. 10, No. 2, pp.115-124. United States: David Publishing Company

10. Kinoshita, E. (2011) 'Why Bubble Economy Occurs and Crashes,' Journal of China-USA Business Review, Vol. 10, No. 2, pp.111-120. United States: David Publishing Company

11. Kinoshita, E. (2011) 'Globalization or Isolation? Recardo's Mode,' Journal of China-USA Business Review, Vol. 10, No. 10, pp.1-9. United States: David Publishing Company

12. Kinoshita, E. (2012) 'A Proposal of Thetical Economy and Antithetical Economy--Mechanism of Occurrence and Collapse of Bubble Economy,' Journal of Business and Economics, Vol. 3, No. 2, pp.117-130. United States: Academic Star Publishing

13. Kinoshita, E. (2015) 'Thetical and Antithetical Business Management,' Journal of Business and Economics, Vol. 6, No. 6, pp.1086-1096. United States: Academic Star Publishing

14. Kinoshita, E. (2015) 'A Proposal of Thetical Economy and Antithetical Economy by Using Operations Research Techniques,' European Scientific Journal, July 2015 edition, Vol. 11, No. 19, pp.29-48. 